\title{
The Expansion Trajectory: Trademark Jurisprudence in the Modern Age
}

Kenneth L. Port

Mitchell Hamline School of Law, ken.port@mitchellhamline.edu

\section{Publication Information}

92 Journal of the Patent and Trademark Office Society 474

\section{Repository Citation}

Port, Kenneth L., "The Expansion Trajectory: Trademark Jurisprudence in the Modern Age" (2010). Faculty Scholarship. Paper 199. http://open.mitchellhamline.edu/facsch/199 


\title{
The Expansion Trajectory: Trademark Jurisprudence in the Modern Age
}

\author{
Abstract \\ American trademark law is expanding. The expansion began with the adoption of \\ the Lanham Act in 1947. At that time and ever since, commentators and law makers \\ alike referred to the Lanham Act as a codification of the existing common law. In fact, \\ this codification was a selection and expansion of the common law. The United States \\ has continued to expand trademark jurisprudence: from incontestability, to cybersquatting, \\ to dilution - the notion of what it means to protect a trademark has \\ continued to expand. During this time, the Commerce Clause on which American \\ federal trademark protection is based has not changed. \\ The result of this inextricable expansion is that trademark jurisprudence in the \\ United States is becoming muddled. Originally, trademark protection was justified \\ as a right of exclusion that was granted to the user of a sign for their exclusive use \\ for as long as they used it and to the extent they used it. Now, the trademark right \\ has come to resemble the moral right of attribution andlor integrity of civil law \\ copyright systems.
}

This may be appropriate if the nation had a purposeful debate or discussion on turning the United States trademark system into a system of moral rights. However, no such discussion has taken place. Rather, Congress has enlarged the trademark right at the behest of special interests without paying attention to the consequences. One consequence is that trademark jurisprudence now has a striking resemblance to that of the protection offered by moral rights in civil law countries.

\section{Keywords}

trademark dilution, moral right, right of exclusion

\section{Disciplines}

Intellectual Property Law 


\title{
The Expansion Trajectory: Trademark Jurisprudence in the Modern Age
}

Kenneth L. Port

\begin{abstract}
:
American trademark law is expanding. The expansion began with the adoption of the Lanham Act in 1947. At that time and ever since, commentators and law makers alike referred to the Lanham Act as a codification of the existing common law. In fact, this codification was a selection and expansion of the common law. The United States has continued to expand trademark jurisprudence: from incontestability, to cyber squatting, to dilution - the notion of what it means to protect a trademark has continued to expand. During this time, the Commerce Clause on which American federal trademark protection is based has not changed.

The result of this inextricable expansion is that trademark jurisprudence in the United States is becoming muddled. Originally, trademark protection was justified as a right of exclusion that was granted to the user of a sign for their exclusive use for as long as they used it and to the extent they used it. Now, the trademark right has come to resemble the moral right of attribution and/or integrity of civil law copyright systems.

This may be appropriate if the nation had a purposeful debate or discussion on turning the United States trademark system into a system of moral rights. However, no such discussion has taken place. Rather, Congress has enlarged the trademark right at the behest of special interests without paying attention to the consequences. One consequence is that trademark jurisprudence now has a striking resemblance to that of the protection offered by moral rights in civil law countries.
\end{abstract}


Table of Contents

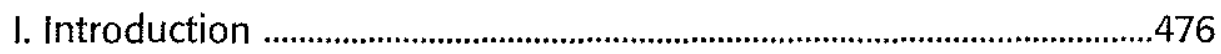

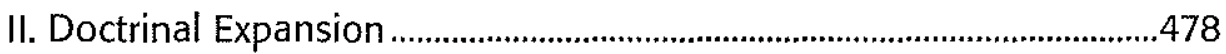

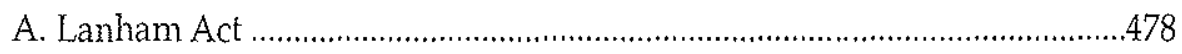

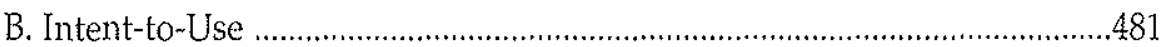

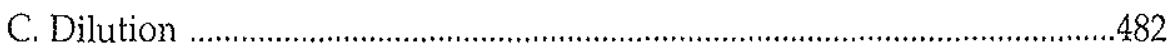

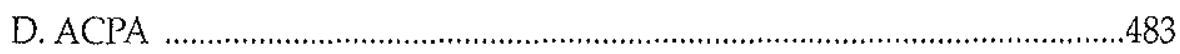

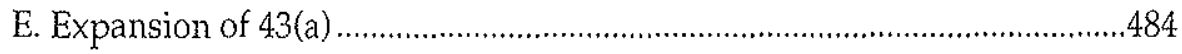

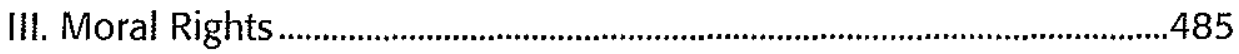

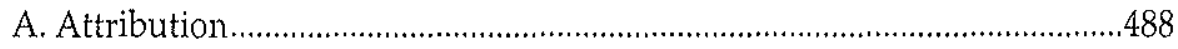

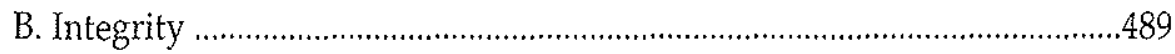

IV. Tension between the Courts and Congress

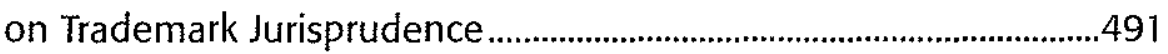
A. Dilution
B. Fair Use .492
C. Courts Resist; Congress Favors

V. Normative Result: The US Protects the Personality of a Trademark ..495

VI. Conclusion 497 


\section{Introduction}

In 1994, I predicted that a federal statute protecting trademarks from dilution was a dangerous notion as follows:

A federal statute protecting "super trademarks" from dilution would create a copyright in the mark itself, as well as in the abstract idea of the mark in the minds of the consumer and manufacturers... Under dilution theory, the trademark holder not only controls each expression of the mark, but also attempts to control the manner in which consumers or other manufacturers perceive of the mark. In this matter, dilution theory attempts a monopolization of the idea of the work even outside of any use. In that respect, dilution theory violates the idea/expression dichotomy?

In 2000, I described and analyzed the expansion of American trademark jurisprudence and claimed that the United States had inadvertently created a Civil Law of trademarks, rather than remaining honest to our common law origins.?

In the interim, this predicted expansion has continued unabated. Trademark jurisprudence in the United States has inextricably expanded since the inception of the Lanham Act in 1947..$^{3}$ This article presents several examples of this expansion. Incontestability, a doctrine created with the Lanham Act, was the first step."
Trademark jurisprudence settled into a groove until 1989 when Congress created the intent-to use (ITU) system. ${ }^{5}$ In 1996, Congress enacted the Federal Trademark Dilution Act (FTDA). ${ }^{6}$ In 2000, the Anticybersquatting Consumer Protection Act (ACPA) was enacted.' Throughout the history of the Lanham Act, Section 43(a) has gradually been expanding. However, it received a huge jolt in 1995 when the Supreme Court held that color alone could act as a trademark. ${ }^{8}$

The result of this inextricable expansion is that trademark jurisprudence in the United States is becoming muddled. Originally, trademark protection was justified as a right of exclusion that was granted to the user of a sign for their exclusive use for as long as they used it and to the extent that they used it. Now, the trademark right has come to resemble the moral right of attribution and/or integrity of civil law copyright systems.

This may be appropriate if the nation had a purposeful debate or discussion on turning the United States trademark system into a system of moral rights. However, no such discussion has taken place. Rather, Congress has enlarged the trademark right at the behest of special interests without paying attention to the consequences: one consequence being that trademark jurisprudence now has a striking resemblance to that of the protection offered by moral rights in civil law countries.

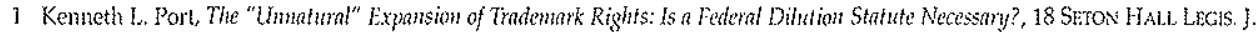
433, 486-87 (1994)(winner, Ladas Memorial Award).

2 Kennetly L. Port, The Congressional Expansion of American Thatemnk Law: A Civil Law System in the Making, 35 Wake Forest L. Rev. $827(2000)$

3 15 U.S.C. \$. 1052 (2008).

4 See 15 U.S.C. $\$ \$ 1064,1065,1115$ (2008).

5 See 15 U.S.C. $\$ 1051$ (2008).

6 Pub. L. No. 104-98, \$\$ 3(a), 4, 109 Stat. 985, 985-86 (effective Jan. 26, 1996) (codified as amended at 15 U.S.C. \$\$ 1125, 1127 (2008)).

7 Pub. L. No. 106-113, \$§ 3001-10, 113 Stat. 1501A.545, 545-52 (1999) (effective Nov. 29, 1999) (codified at 15 U.S.C. \$1125(d) (2008)).

8 See Qualitex Co. v. Jacobson Prods. Co., 514 U.S. 159 (1995). 
Although some American scholars have made a career out of lobbying for moral rights, others have questioned either the necessity" or the desirability" of adopting a moral right scheme. Regardless of how one might come down on this issue, American trademark rights today have come to resemble the moral rights of attribution and integrity. Congress has done this with no discussion or conversation about whether or not this is a good idea. Worse yet, when the Supreme Court has attempted to reign in this expansion, Congress has simply overruled the Court. ${ }^{12}$

Congress seems serious about affecting this expansion. Congress has been pushing this expansion most strongly in the last decade. Congress has been confronted in this expansion by the Supreme Court but to no real effect.1.3 This conspiracy of expansion has gone on with no debate or discussion with the American people to decide if society wants an expanded trademark system.
Rather, this conspiracy of expansion has resulted in small to medium sized corporations feeling extorted by large corporations over trademark rights. ${ }^{14}$ Therefore, this problem is not merely jurisprudential. In fact, it is quite real.

As trademark rights expand to resem ble the moral rights of attribution and integrity, they become stronger and broader in scope. When they become stronger and broader in scope, they are asserted more aggressively against competitors. This results in competitors changing their trademarks to avoid conflict. We know this is happening. ${ }^{.5}$ This article tells the story of how, legislatively, this is done.

Section II presents each major expansion in American trademark history since the Lanham Act was created. Section III portrays the moral rights of attribution and integrity and how trademark protection has come to resemble them. Section IV discusses the tension that has been created between the Supreme Court and

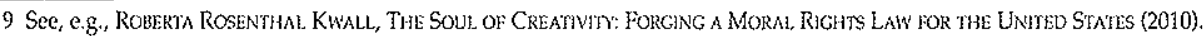

10 See Rebecca Stuart, A Work of Heart: A proposal for a revision of the Visual Artists Rights Act of 1990 to Bring the United States Closer to International Standards, 47 SANTA CI.ARA L. REV. 645, 678-79 (2007) (The right of divulgation "las not proven to be a very important right in the international community."); Kimberly Y.W. Holst, A Case of Bad Credit?: The United States and the Protection of Monl Rights in

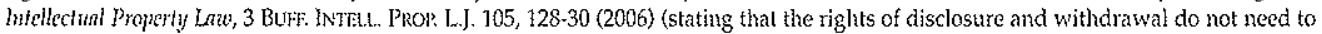
be prolected under the Berne Convention, because common law already protects these riglats; by contrast protection for attribution and integrity have not had the same support from the courts). See also MELWLLE B. NIMMER \& DAVD NMMMER, NIMMER ON COPYRIGHT: A TREATIS: ON THE LAW OF LITERARY, MUSICAL AND ARTISTKC PROPERTY, AND THE ProteCTON OF IDEAS 8D.01, 8D-8 n.24 (1994) ("Note that a divulgation right may exist in Berne by implication."); SAM RICKEISON, THI BERnt CONVENTON FOR THE ProTECMON OR LMERARY AND ARTSIIC WORKs: 1886-1986, 476 (1987) ("There is no reference to [the righl of disclosure] in article 6[bis], but it is possible to argue that such a rigltt is required to be protected, by implication.").

11 Elizabeth Dillinger, Mutilating Picasso: The Case For Amending the Vistal Atists Rights Act to Provide Prolection of Mornl Rights After Death, 75 UMKC L. Rev, 897, 906 (2007) ("we should enact a high wall to prevent disnuptive moral rights concepts from creeping into U.S. law.") (quoting senator Orrin Hatch).

12 Following Moseley v. V Secret Catalogue, hnc, 537 U.S. 418 (2003) the Federal Trademark Djlution Act (TDA) of 1995 was amended by the Trademark Dilution Revision Acl (TDRA) of 2006, Pub. L. No. 109-312 \$\$ 2, 3(e), 120 Stat. 1730, 1733 (effective Oct. 6, 2006) (codified in 15 U.S.C. \$ 1125 (c) (2008).

13 See Wal-Mart Stores, Inc. v Samara Brothers, Inc., 529 U.S. 205 (2000); TrafFix Devices lnc. v. Marketing Display's knc, 532 U.S. 23 (2001); Moseley v. V Secret Catalogue, Inc, 537 US 418 (2003); Dastar Corp. v. Twentieth Century Fox Film Corp., 539 U.S. 23 (2003); KP Permanent Make-Up, Inc. v. Lasting Impression I, Inc., 540 U.S. 1099 (2004).

14 See eg, Michael Barbaro \& Julie Creswell, With a Trademark in lis Pocket, Levi's Turns to Suing Its Rivals, N.Y. Times, Jan. 29, 2007, at $A 1$, available at http://wwwnytimes.com/2007/01/29/business/29jeans.html (Levi Strauss has filed nearly 100 lawsuits against competitors since 2001; Tonny Sorensen, chief executive of Von Dutch Originals, a relatively new competitor to Levi, claimed the purpose of the lawsuits is simply to "scare people away").

$15 \mathrm{ld}$.
} 
Congress over the appropriate scope of trademark protection. Section V presents some normative conclusions that this problem manifests.

\section{Doctrinal Expansion}

The trademark right in the United States has been on an inextricable course of expansion since (and including) the inception of the Lanham Act. The United States Congress has known only one direction in trademark law: expansion. ${ }^{16}$ However, the trademark law can expand only so much until it begins to resemble some other law such as the moral right. When it resembles a moral right, the basic theoretical justification for that trademark protection changes. ${ }^{17}$ Where it once used to be a right of exclusion limited to the extent of use and the duration of use, its justification has now changed to protection for protection's sake, which is not the original intent of trademark protection. ${ }^{18}$

\section{A. The Lanham Act}

The Lanham Act went through a tortured history before it was finally passed in the days following World War II. There were multiple attempts between 1938 and 1946, when it was finally passed." The legislative history of the Lanham Act tells us that this is a codification statute-no new substantive law was created with the Lanham Act. It merely codified the existing common law with the intention of operating as a registration statute. ${ }^{20}$ As we shall see, this legislative history has not been realized. Many new substantive rights have been granted. The first is the notion of "incontestability." ${ }^{21}$ A trademark registration can become incontestable anytime after five years of consecutive use of mark on the identified goods or services. ${ }^{22}$

16 See e.g., Willis R. Davis, Comment, Intent to Applications for Trademark Registration, 35 WAvent L. Rev. 1135, 1154 (1989) (stating that Congress' adoption of the intent-to-use system represents "a major practical and theoretical shift" from traditional U.S. (rademark law); Natalie J. McNeal, Victorin's Dirty Little Secret: A Reweling Look at What the Federni Trademark Dilution Act is Trying to Conceal, 56 OKt.A. L. Rev. 977, 977, 983-84 (2003) (discussing Congress' rapid and unexpected passage of the 1995 Federal Trademark Dilution Act; an act which talls outside of the original scope of the Lanham Act); K.]. Greene, Abusive Tradomak Litigation and the horetible Shrinking Confusion Doctrine-Trademark Abuse in the Context of Entertammen Medis and Cuberspace, 27 Harv. J.L. \& I'ub. Pol'y 609, 610-13 (discussing how Congress' expansion of trademark rights, particularly in regards to the Anti-Cybersquatting Consumer Protection Act of 1999, has been "dramatic")

17 The Lanham Act's purpose is to protect the relevant consumer and ensure fair competition; it does not confer any property right in a trademark alone. See United Drug Co. v. Theodore Rectanus Co, 248 U.S. 90, 97 (1918) ("There is no such thing as property in a trade-mark..."). When protection begins to extend beyond simply indicating the source or origin of a product or service, trademark law is no longer is serving its originally intended purpose. Id.

18 One example of this is the "Intent to Use" provisions, which have the effecl of creating rights in trademarks prior to their actual use. See 15 U.S.C. $\$ 1051$ (b) (2008). Creation of rights before actual use is not an uncommon trait of civil law trademark jurisdictions, but is generally inconsistent with common law jurisdictions, especially the United States where Irademark riglts are based on the Commerce Clause of the Constitution, which requires "interstate commerce" or actual use. See U.S. Const. art. I, \$8, cl. 3; 15 U.S.C. $\$ 1127(2008)$.

19 While the act was originally introduced in 1938, the intervening events of World War II caused the passage of the Lanlam Act to be delayed until after the war came to an end. 1 THOMAS MCCARTHY, MCCARJHY ON TRADEMARKS ANO UNFAR COMPITITLN \$5:4 (4th ed. 2007). See also FrMink H. Foster \& Robert L. SHOOK, PATENT, COpYrights, AND TRAdemarks 23 (2d. ed. 1993).

20 Se 15 U.S.C. \$1127 (2008); J. THOMAS MCCARTHY, MCCARTYY ON TRADEMARKS AND UNFAR COMPETrTON \$ 11:49 at 11-105 (4th ed. 1996) (stating thal the act has been recognized as a stalutory restatemenl of the corresponding common law). In passing this act congress also hoped to bring American law into conformity with the more liberal principles of a number of foreign countries, standards to which the United States had pledged adherence by treaty and convention. S. Rep. No. 79-1333, at 3 (1946), reprinted in 1946 U.S.C.C.A.N. 1274, 1277. See also, Kohler Co. v. Moen, Inc, 12 F.3d 632, 647 (7th Cir. 1993) (Cudaly, J. dissenting)(when the two conflict, patent law should displace trademark law because patent law is recognized in the Constitulion while trademark law is a mere codification of the common law). 
Given the advantages offered to an incontestable mark, it is remarkably simple to obtain incontestable status. An applicant merely needs to file a Section 15 Affidavit and pay the proscribed fee to obtain an incontestable mark. ${ }^{23}$ There is no substantive evaluation of the mark or the claimed use. The PTO merely has a filing clerk check to make sure that the correct people have signed the Section 15 Affidavit and other very simply formalistic requirements. ${ }^{24}$ After that, the mark is incontestable.

An incontestable mark has many statutorily created advantages over a nonincontestable mark. Merely descriptive marks that have become incontestable are protected from a motion to cancel the registration. ${ }^{25}$ The Supreme Court went along with this expansion in Park $N^{\prime}$ Fly v. Dollar Park and Fly. ${ }^{26}$ There, the Supreme Court held that an incontestable mark could be used offensively, as well as to defend against a motion for cancellation. ${ }^{27}$
Therefore, Park N' Fly was allowed to use the fact that its mark had become incontestable as a basis to sue Dollar Park and Fly for trademark infringement, even though its mark was descriptive and therefore unenforceable. ${ }^{26}$ That is, save for the statutorily created notion of incontestability, Park $N^{\prime}$ Fly would have lost this case and we would likely have many "park and fly" providers at airports around the country. However, because of this statutory gift, Park $N^{\prime}$ Fly prevailed. Therefore, there is only one provider of off-airport parking services under that name. ${ }^{29}$

Another advantage of incontestability is the fact that Section 33(b) of the Lanham Act states that for an incontestable mark, "registration shall be conclusive evidence of the validity of the registered mark and of the registration of the mark, of the registrant's ownership of the mark, and of the registrant's exclusive right to use the registered mark in commerce." ${ }^{130}$ Again, but

23 The current fee for filing a $\$ 15$ declaration is $\$ 200$ per class of goods/services. USPTO Fee Information, hllp:/ www.uspto.gov/web/offices/ac/qs/ope/fee2009 seplember15.lum (follow "Trademark Processing Fees" hyperlink).

24 "The USPYO neither examines the merits of $\$ 15$ Declarations nor 'accepts' $\$ 15$ Declarations. However, the USPYO will review a \$15 Declaration to determine whether il complies with statutory requirements." USP'PO, Trademark Process, Maintain/Review a Registration, http://wwwiuspto.gov/trademarks/process/maintain/prfaq.jsp (last visited Sept. 10, 2010).

25 15 U.S.C. $\$ 1115$ (2008) ("registration shall be conclusive evidence of the validity . . of the registrant's exclusive right to use the registered mark in commerce. ... and shall be subject \{only\} to the following [nine defenses.").

26469 U.S. 189 (1984).

27 Id. at 205; see also id. at 193 (stating that "[t]he decision below is in direcl conflicl with the decision of the Court of Appeals for the Seventh Circuit in Union Carbide Corp. v. Ever-Ready, Inc., 531 F.2d 366, cert. denied, 429 U.S. 830 (1976). . . we now reverse," lhereby clarifying the split that developed in the circuit courts regarding offensive use of incontestabjlity).

28 Id. at 205 ("TThe holder of a regislered mark may rely on incontestability to enjoin infringement and that such an action may not be defended on the grounds that the mark is merely descriptive.").

29 Because use of the word combination "park and fly" was bamed, "Dollar Park and Fly" was forced to change their name to "lark Shultle N Fly." See http://wwwhoovers.com/company /Dollar_..Park_and_Fly._ho/rrcrhlhhk-1.html (Last visited Sept. 10, 2010); www.parkshultleflypdx.com/ (last visited Sept. 10, 2010) (showing "Dollar Park and Fly's" current address in Porlland, Oregon, as the same as "Park Shuttle N Fly's"). Despite losing the legal battle, the word "Shuttle" in "Park Shuttle N Fly's" logo appears so small that the logo actually appears as "Park N Fly." Id. See also their sister company's website, boldly named "Seattle Park N Ily," available at http:/ www.parknlyseattle.com/. The company filed a similar version of this logo with the USP'TO in 1999, but failed to see it though to registration. See Registration No. 75640460 (Filed on Feb.12, 1999). Holding several trademarks of their own, there is also a "Park Sluttle and My" http:// www.parkshuttlefly.com/ (last visited Sept. 10, 2010) located in Boston; no affiliation with "Park Shutle N Fly"). See their website, available at http:/www,parkshultefly.com/. Other competitors include: "Park, Sleep, Fly," available at littp://www:parkslecply.com (last visited Sept. 10,2010); "Park, Ride, Fly," available at http:/ www.parkrideflyusacom (last visiled Sept. 10, 2010); and "Park, While U Fly," available at htlp://www.stayl23.com/ (last visited Sept. 10, 2010).

30 15 U.S.C. $\$ 115$ (2008)(continuing on to list only nine available dejenses for a dejendant to contest an infringement claim from the holder of an incontestable mark). 
for the statute, a trademark owner could never claim that its mark was "conclusive evidence" of anything. ${ }^{31}$ A claimant would have to prove each and every element of its cause of action. Therefore, the right of incontestability is quite strong., ${ }^{32}$

If the Lanham Act is a codification of the common law of trademarks, ${ }^{33}$ one would naturally wonder where this notion came from. Which state in 1946 had a judicially created notion that would resemble incontestability? Of course, no such state existed. The best record we have of the origin of the notion of incontestability is that it was once fixed in the United Kingdom Trademark Act. ${ }^{34}$ In a loose sort of a way, the US common law incorporated the UK common law, but that ended by 1946.35

Therefore, Congress made choices in 1946 when it included the notion of incontestability in the Lanham Act. The only

31 See also 15 U.S.C. $\$ 1065$ (2008) (indicating that incontestable marks are conclusively presumed vafid)

32 particularly in the Sixth and Eleventh Circuits where incontestable marks have been held as presumptively strong, even when they are descriptive. See Dieter v. B \& Hindus., 880 F.2d 322, 329 (11th Cir, 1989); Wynn Oil Co. v. Thomas, 839 F.2d 1183, 7187 (6th Cir. 1988). However, admittedly they are in the minority. See Homes \& Land Affiliates, LLC v. Homes \& Loans Magazine, LLC, 598 F. Supp. $2 d 1248,1261$ n. 12 (M.D. Fla 2007) ("Other circuits conclude that an otherwise weak mark is not made strong for the purposes of the likelihood-of-confusion analysis because of its incontestable status. See Oreck Corp. v. U.S. Floor Sys., hic., 803 I.2d 166, 171 (5th Cir. 1987) ("lnconlestable status does not make a weak mark strong."); See also Lone Star Steakhouse \& Saloon, Inc. v. Alpha of Va., 43 F.3d 922, 935 (4th Cir. 1995) (stating that "incontestability affects the validity of the trademark but does not establish the likelihood of confusion necessary to warrant protection from infringement"); Gruner + Jahr USA P'tbl'g v. Meredith Corp., 991 F.2d 1072, 1077-78 (2d Cir. 1993) (implying that the marketplace strength of an incontestable mark may be challenged); Munters Corp. v. Matsui Am., Inc., 909 F.2d 250,252 (7th Cir. 1990) (incontestable status does not preclude consideration of a mark's strength").

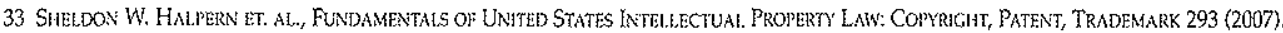

34 In 1875 and 1883 Great Britain enacted statutes which essentially provided that registration of a mark would become conclusive evidence of the registrant's right to the exclusive use of the mark after five years after initial registration. Although these statutes never use the word "incontestable," they are otherwise strikingly similar to the relevant provisions of the current Lanham Act. See An Act to Eslablish a Register of Trade Marks, 38 \& 39 Vict., ch. 91, 33 (1875) reprinted in ROCER W. WALLACE \& JOHIN B. WILLIAMSON, THE LAW ANo Practice Relating To Letters Paffent For Invmintons 612 (1900); An Act to Amend and Consolidate the Law Relating to Patents for Inventions, Registration of Designs, and of Trade Marks, $46 \& 47$ Vict, ch. 57, 76 (1883) discussed in Gratime B. DiNwoODit: \& Mark D. Janis, Trademark Law and THeORY: A HANdeOOK OF CONTEMPORARY RESEARCh 28 (2009).

35 Trademarks have been officially recognized by English common law as early as 1618 . See Southern v. How, Popham's Reporls 143, 144 (1618), 79 Eng. Rep. 1243, 1244 (K.B. 1907)); Keith M. Stolte, How Early Did Anglo-American Thademark Law Begin? An Answer to Schechter's Conmdrtm, 8 Forouam Intel.. Prop. MedA \& ENT. L.J. 505, 517 (1998). In 1776, following the American Revolution, the newly independent states enacted "reception statutes" enabling courts to readopt and develop the British Common Law they had previously adhered to while colonies. Charles A. Bane, From Holt and Mansfielt to Story to liewellyn and Mentschikoff: The Progressive Developnent of Commercid Law, 37 U. MiAt L. REv. 351, 363 (1983). By guaranteeing that judicial proceedings would follow the course of established common law, the Northwest Ordinance, approved by Congress in 1787, furthered this notion for the advancing territories. Peter $L$. Strauss, Federal Courts and the Common Law, 53 Ala. L. Rev. 891,910 n,96 (2002). In this way, historic Anglo-Saxon based common law was eventually incorporated in all the newly created states (except Louisiana, who adopted a bijuridical system based on the Napoleonic Code of 1804). Washington Legal Foundation v. Legal Foundation of Washington, 271 1.3d 835, 853 (9th Cir. 2001); Guy Canivel, French Civil Law Between Past and Revionl, 20 CON. J. INT'L L. 111, 118-20 (2004). As the reception statutes became obsolete, the states eventually enacted new laws. New York was the first to enact a slate trademark law in 1845. EDWAro S. Rocliks, GOOD WILl, Trade-MARkS AND UNEAR Trading 48 n.12 (1919). Despite only 62 trademark cases having been decided in the United States by 1870 (40 of which were in New York), the first Federal Trademark law was enacted. Act of July 8, 1870, c. 230, 16 Stat. 198; ANNe Gitson LéloNor et al., GILSON ON Tradesarks \$1.01[2] (Lexis 2010). Unfortunately, under Suprene Court review in Trade-Mark Cases, 100 U.S. 82 (1879), the 1970 trademark law did not meel constitutional nuster. Pressured by the international demand from commerce treaties with several civil haw countries (Russia, Belgium and France between 1868-1869), Congress had failed to ground the law in the commerce clause as Thomas

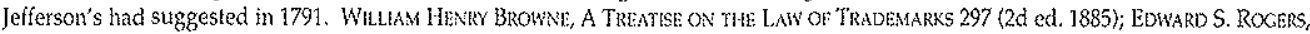
GOON Will, Trade-Marks and UNBar Trudng 48 (1919). The next significant altempt at a federal trademark registration came with the Act of 1905. Act of Teb. 20, 1905, ch. 592,33 Stat. 724. England the same year. The Trade Marks Acl, 1905: 7 Edw. VII. Ch. 15. Both American and English versions went through various amendments, until a new English Act was eventually passed in 1938. Trade Marks Act 1938; $1938 \mathrm{cl} .22$ 1,2 Geo. 6. This Act fundanentally changed the English system by permilting registration based on intent-to-use, creating an examination-based process, and creating an applicalion publication system. England's new act greatly influenced Fritz G. Lanham, who the same year first introduced to Congress the Anerican version. SHOEN ONO, OVERVIIW OF JAPANFSE TRADEMARK LAW (2d ed. 1999). See also Moseley v. V Secret Catalogue, 537 U.S. 418, 428 (2003) (" The United States took the Itrademark and untair competition] law of England as its own") (quoling B. Pattshall, D. HILLIARD, \& J. WELCH, TRADEMARKS AND UNFAR COMPETIION 2 (4th ed. 2000)) (alteration in original). This act was finally passed in 1946, and took effecl one year later. 
source or jurisdiction that included a notion of incontestability was the UK. Congress elected to ignore the common law of the rest of the United States and embrace the UK version of incontestability." Therefore, more appropriately, the Lanham Act should be said to be a "codification (of the laws we liked) statute."

Incontestability was a serious expansion of the trademark law as it existed in the United States in 1946. ${ }^{37}$ To be sure, it is a valuable encouragement for firms to register trademarks. Given the incontestability provisions, along with its conclusive evidence provisions, it would seem a violation of corporate fiduciary duties to not claim incontestibility after five years of continuous use. ${ }^{35}$ However, this is only one of example of many to follow of Congress expanding the trademark right way past any notion of what the Common Law of trademarks had been prior to 1946.

\section{B. Intent To Use}

The so-called Intent-to-Use ("ITU") ) $^{39}$ system is yet another expansion of the
American notion of trademark protection. Passed in the Trademark Revision Act of 1988, the ITU system allows a trademark claimant to register its intended use of the mark with the PTO.40 Although section 7(c) of the Lanham Act requires that any effect of the ITU system is "contingent upon registration of the mark," in reality the ITU system does grant several important rights that are not contingent upon registration of the mark. By making "registration of the mark" a requirement, Congress attempted to make ITU rights contingent upon use of the mark in commerce, thereby preserving the constitutionality of the ITU system. ${ }^{22}$ However, under the ITU system, before the mark is used in commerce, an actual trademark application is filed with the PTO and thereby a record of this application is created. This application will be disclosed in all subsequent and relevant trademark searches. This gives notice to all subsequent actual users of that mark that some entity has claimed priority to that mark. Therefore, although not a part of the statute, an ITU application has a great sig-

\footnotetext{
36 Contrary to the Supreme Court's interpretation, English judges relused to recognize a registrant's right to the exclusive use if a showing was made that the mark lad never been properly registered in the first place. See Park $N^{\prime}$ Fly v Dollar Park and Fly, 469 U.S.
} $189,209 \div 8$ (1984) (Stevens, J., dissenting).

37 See also Maya Alexandri, The Intemational News Qunsi-Property Pardigm and Tradomark hontestability: A Call for Reworiting the Lamhan Acl, 13 Harv J.L. \& Tech. 303, 304-307 (2000)(equaling incontestability to the dubious creation of quasi-properly rights in news).

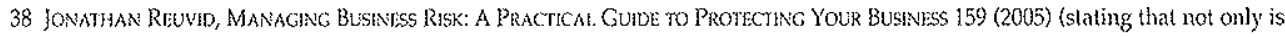
it necessary to register a trademark, but it is also imperative that a company monitor the marketplace for infringing competition and take action when necessary).

39 The reasons cited for instituting the intent-to-use system were to eliminate foreign advantage in U.S. trademark registration, to increase overall value of the U.S. trademark system, and to bring the U.S. trademark system up to speed on current business pratices around the world. S. Rep. No. 100-515, at 5 (1988), as reprinted in 1988 U.S.C.C.A.N. 5577,5581. The intent-to-use notion was proposed multiple times throughout the 20th century but had been held unconstilutional in United States v. Steffens, 100 U.S. 82 (1879) due to the lacking 'use in interstate commerce' tequirement. See Sheldon Klein, Tradomark Low Bill: Marked huprowement in Registration Rutes, 11 Ligat. TMms, May 30, 1988, at 16.

4015 U.S.C. $\$ 1051(2008)$.

41 15 U.S.C. $\$ 1057$ (c) (2008).

42 Unlike patent and copyright protection which are expressly provided for in the Constitution, U.S. trademark protection is derived from the Constitulion's commerce clause. U.S. Const. art. I. $\$ 8 \mathrm{cl} .3$.

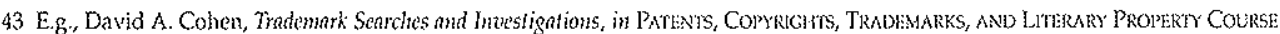

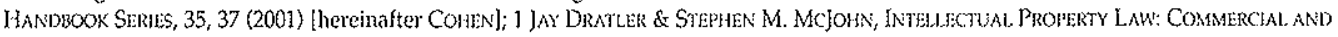
INDUSTHAAL PROPERTY, $\$ 1.06$ (2003). 
nificant deterrent effect for the ITU claimant. As firms are naturally conflict adverse, ${ }^{44}$ once a mark with prior ITU rights is discovered in a trademark search, firms will work around such an ITU application, even if no use is ever made. Because the ITU registration gives the applicant three years in which to use the mark, ${ }^{45}$ during that three year time period, a third party will not know if actual use will ever occur. As such, that third party would likely steer in a different direction, even if use of the ITU applicant was never to be realized. That is, to risk adverse firms, the ITU system has a real and specific effect, even if all statutory rights are subject to use in actual commerce.

Through the ITU system, trademark rights in the United States have expanded. Without recognizing it as such, the United States has taken a large step toward harmonizing how trademark rights are created. Most Civil Law systems create trademark rights upon registration, not upon use. ${ }^{46}$ In fact, the ITU system is largely in line with all civil law nations, as use is not required in civil law countries prior to or as a "contingent" of registration. ${ }^{47}$ Even though harmonization was not a stated goal for the ITU system when debated by Congress, it does result in a serious expansion of the trademark right and continues the inextricable trend of expansion.

\section{Dilution}

In 1996, the Federal Trademark Dilution Act (FTDA) was signed into law by then President Clinton..$^{4}$ This law did more to expand American trademark law than any other act of Congress. The FTDA allows a holder of a famous mark the ability to enjoin the use of the same or similar mark on completely unrelated goods or services." Under traditional trademark jurisprudence, before a cause of action for trademark infringement will lie, the defendant has to be in competition with the plaintiff,

44 See COIEN, supra note 43, at 37 (stating that a trademark search is "appropriate, and possibly necessary" to avoid costly and time consuming conflicts with other potential mark holders); 3 MCCARTHY ON TRADEMARKS AND UNFAIR COMPETTION $\$ 19: 6$ (4th ed. 2010) (advising companies to "obtain a preliminary determination as to possible conflicl with previously used but unregistered marks, applied-for marks, and registered marks").

45 Although six months is the initial prescribed time period in which to use the mark in commerce an additional thirty months of extension may be granted to the mark liolder for a mere showing of good cause and payment of the requisite fees. 15 U.S.C. $\$ 1051(d)(2008)$. Additionaliy, even in the event of inappropriate extension request protocol, a mark holder may still redeen hin or herself by simply showing that the delay was unintentional. 15 U.S.C. \$ 1051 (d)(4) (2008).

46 Sholyoho [Japanese Trademark Act], Law No. 127 of 1957, art. 18. "A trademark riglt slaall subsist upon its registration." (Translation by author)

47 See e.g., Clark W. Lackert, Global Trademark/Copyrights Practice-Protection and Enforcement lssues in PATENTS, CorYriGnTS, Trademarks, AND Lithkary Properm COURS: HANDBOOK SFriEs, 171, 201 (1997). Examples of Civil Law countries that determine trademark rights by registration instead of use include Germany, Japan, France, Spain, Italy, Korea, China, and Latin America. Id. Although registration is nol contingent upon use in these countries under specific limited circumstances trademark rights can be acquired through use alone. Thomas J. Hoffmann, Advanced Seminar on Trademark Law in Patents, in CopYRIGHTS, TRADEMARKS, AND LITERARY ProperTy COURSE: HANOBOOK SERIES, 253 (1995)(noting that in Japan a party seeking trademark rights through use must show a major portion of the public nust be aware of the mark and in Germany more than $50 \%$ of the public must be aware). See also, Article 5, Algerian Ordinance relating to Trademarks, No. 66-57 March 19, 1966; Article 18 Japanese Trademark Law No. 127 Apr. 13, 1959; Article 59, Brazilian Trademark Law No. 5772 Dec. 21, 1971.

48 Federal Trademark Dilution Act of 1995, Pub. Ł. No. 104-98, 109 Stat. 985,986 (1996) (codified at 15 U.S.C. \$1051, 1125, 1127 (2000) (amended 2006)). The Act was passed by Congress in December 1995 and signed by President Clinton on January 16, 1996.

4915 U.S.C. \$1125(c) (2008). The FIDA allows the holder of a famous matk injunctive relief when an unauthorized use of the mark causes dilution by either "blurring" or "tarnishment." Id. The FTDA, however, limits the action to marks which are famous. A famous trademark is one that is "widely recognized by the general consuming public of the United States as a designation of source of the goods or services of the mark's owner." 15 U.S.C.A. \$1125(c)(2)(A) (2008). 
or within the natural zone of expansion of the plaintiff. ${ }^{50}$

For example, although Kodak brand pianos do not infringe the KODAK mark, it does dilute the KODAK mark..$^{51}$ Dilution, we are told, is defined as the lessening of the capacity of a mark to distinguish itself. ${ }^{52}$ That is, the mere existence of another KODAK mark in the world reduces the famous Kodak Company's ability to distinguish itself. Therefore, it is actionable, even though there is no competition and even though there is demonstratively no confusion possible. ${ }^{53}$

Some have claimed that dilution makes the trademark subject to property ownership..$^{54}$ Some have argued that it makes the trademark subject to copyright-like protection. ${ }^{\text {ss }}$ Some argue that it is necessary as marks evolve and become famous they must be protected them from freeloaders so that firms will continue to make the investment in the marks. ${ }^{56}$ No one argues however that this was part of the original common law of trademarks. Everyone agrees that it is an expansion of the United States trademark right.

\section{ACPA}

The Anticybersquatting Consumer Protection Act (ACPA) also expanded American trademark jurisprudence. The ACPA was enacted to prevent cybersquatting, the act of using someone else's trademark as a domain name.5 The ACPA's protection was intended to provide a cause of action for the registering someone else's trademark as a domain name in bad faith. ${ }^{5 s}$

The ACPA also created in rem jurisdiction. This allows a harmed trademark owner to sue the domain name itself in the event the domain name registrant provides the relevant Registrar with a false name or address. ${ }^{59}$

50 See Lynda J. Oswald, Article."Tamishmen" and "Bhirring" Under the Federal Trademark Dihtion Act of 1995, 36 AM. Bus. L.J. 255, 259 (1999) ("The traditional cause of action under trademark law is for infringement, which has its basis in the tort of deceit. Trademark infringement occurs when one party (lhe junior user) uses a trademark (the junior mark) that is identical or substantially similar to the existing mark (the senior majk) of another user (the senior user) on compeling goods, such that prospective purchasers are likely to be confused, mistaken, or deceived as to the identity or source of the goods involved.").

51 See H.R. Rep. No. 104-374 at 3 (1995) (listing three hypothetical examples of dilution of famous marks contemplated by the U.S. House of Representatives, including: Dupont Shoes, Buick aspirin, and Kodak pianos).

52 See Federal Trademark Dilution Act (TDA), Pub. L. No. 104-98, \$\$ 3(a), 4, 109 Stat. 985, 985-86 (codified as amended at 15 U.S.C. $\$ \$ 1125,1127$ (2008)). The TDA defines dilution as "the lessening of the capacity of a famous mark to identify and distinguish goods or services, regardless of the presence or absence of (1) competition between the owner of the famous mark and other parlies, or (2) likelihood of confusion, mistake or deception." Id.

53 See 15 U.S.C. § $1125(\mathrm{c})(1)(2008)$.

54 See Lynda J. Oswald, Article:"Tamishmen" nud "Bhming" Under the Federal Trademark Dihtion Act of 1995, 36 AM. Bus. L.J. 255, 262 (1999) (comparing dilution to the tort of trespass; like trespass, dilution is based upon an injury to the trademark holder and the unjust enrichment of the parly diluting the mark).

55 See Daniel H. Lee, Renedying Past and Funw Harm: Reconciling Conflicting Circtit Comt Decisions Under the Federal Thademark Dihtion Act, 29 Pexp. L. REv. 689, 697-99 (2002); Robert N. Klieger, Tradentark Dihtion: The Whithing Awny of the Rational Basis for Trademark Protection, 58 U. PTT. L. RLV. 789,847 (1997).

56 See H.R. Rep No. 104-374 (1995), reprinted in 1995 U.S.C.C.A.N. 1029, 1030 (stating that FTDA was created by Congress in parl to "enourage trademark holders to invest in their marks to achieve the famous mark status and to recognize the investments that mark

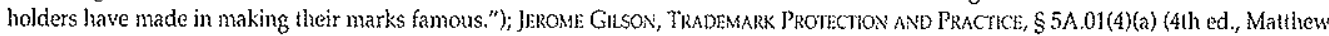
Bench ed., 4th ed., 2004). "The abundant goodwill and consumer loyalty inspired by a well-known mark is the essence of many a successful business' and federal dilution laws protects the substantial investment necessary to advertise and promote the mark." Id.

57 The Anticybersquatting Consumer Protection Act (ACPA) Pub. L. No. 106-113, \$§ 3001-10, 113 Stat. 1501A-545, 545-52 (1999) (effective Nov. 29, 1999) (codified at 15 U.S.C. \$1125(d) (2008).

5815 U.S.C. $\S 1125$ (d) (2008).

$59 \mathrm{ld}$. 
In expanding trademark law in such a way, Congress has made the possibility of legitimate concurrent uses much less likely and consequently given more control to the holder of the trademark. This control which permeates cyberspace is similar to the general concept of moral rights which instill an enduring element of control in the creator of a work over their creation. ${ }^{6}$

\section{E. Expansion of $43(a)$}

The expansion of Section $43($ a) claims under the Lanham Act are rather notorious. ${ }^{62}$ Section 43(a) was first used to protect the shape of the Coke Cola glass bottle. ${ }^{63}$ It has since been used to protect everything from the inside of a Mexican restaurant and its "festive eating atmos" phere, ${ }^{\prime \prime}$ to the green-gold color of press pads in the laundry industry, to the NBC chimes, to the vertically opening motion of a Lamborghini car door. ${ }^{67}$

In Qualitex v. Jacobson Prods., the Supreme Court held that "any" name, symbol, or device that dentified the source or origin of some good or service could be a trademark. ${ }^{\text {ss }}$ The court relied on the word "device" to conclude that even the smell or color of a product could be a trademark if it indicated the source of that good. ${ }^{6}$ Of course, relying on the word "device" for these purposes is historically inaccurate. Originally, the word "device" meant a design mark, not anything under the sun. ${ }^{70}$

There is no doubt that Section 43(a) has resulted in an expansion of trademark protection in the United States. ${ }^{71}$ In 1947, there were few so-called nontraditional trademarks which relied on Section 43(a) for their existence. ${ }^{22}$ Since Qualitex in 1995,

60 See generally Xuan-Thao N. Nguyen, The Digital Thadenark Right: A Trowbling New Eximateritorial Reach of United States Law, 81 N.C. L. Rev. 483 (2003) (arguing that ACPA expands U.S trademark law too far past its territorial boundaries). But see, Robert Nupp, Note, Concurent use of Tradennts on the Intend: Reconciling the Concept of Grographically Delinited Tratemark with the Reatity of the Intermet, 64 OHo ST. L.J. 617, 623 (2003).

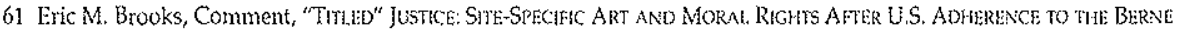
Conventon, 77, CAL. L. REv. 1431, 1434 (1989).

62 Amy B. Cohen, Following the Direction of Traffix: Trade Dress law and Functionality Revisited, 50 IDEA 593 (2010), David Klein, The

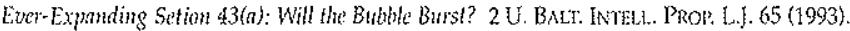

63 Registation No. 1057884 (Feb. 1, 1977), previously 0696147 (Apr. 12, 1960).

64 Taco Cabana Int'l, linc. v. Two Pesos, hrc, 932 [:2d 1113, 1117 (5t1 Cir. 1991), aff'd, 505 U.S. 763 (1992).

65 Registration No. 1633711. See also Qualitex Co. v. Jacobson Prods. Co., 514 U.S. 159 (1995) (resolving a disagreement among the courts of appeal as to whether a color alone may be recognized as a valid trademark).

66 Registration No. 0916522.

67 Registration No. 75883661. See also Automobili Lamborghini SpA v. Lamboshop, Inc, No. 2:07-cv-266-FM-29SPC, 2008 U.S. Dist. LLXIS 52589 (M.D. Fla, July 10, 2008) (finding that defendant violated Lamborghini's federally registered trademarks when it advertised, manufaclured, and sold counterfeit Lamborghini merchandise including fully completed kit cars).

68 Qualitex Co. v. Jacobson Prods, Co., 514 U.S. 159 (1995).

69 "Since luman beings might use a "symbol" or "device" amost anything at all that is capable of carrying meaning, this language, read literally, is not restriclive. . If a shape, a sound, and a fragrance can acl as symbols why, one might ask, can a color not do the same?" $\mathrm{d} d$. at 162.

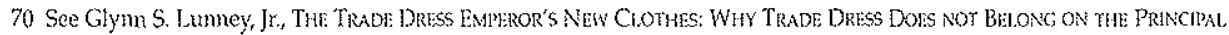

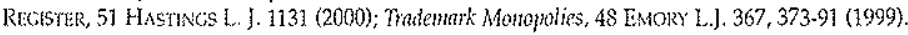

71 Specifically the Trademark Revision Acl of 1988 's use of the words "symbol and device," which an accompanying Senate Report states were employed "so as nol to preclude the registration of colors, shapes, sounds or configurations where they function as trademarks." S. REs. No. 100-515, at 41 (1988), available at lattp:/ / wwwipmallinfo/hosted resources/tipa//rademarks /

PreLanhamAct 097...SR 100-515.pdf. "The definition of 'trademark' is broadened to reflect contemporary marketing practices...." Id.

72 See Kenueth L. Port, On Nontraditioinal Trademarks _._. Northern Kent. L. Rev. __ (2011); 3 (William Mitchell college of Law, Legal Studies Research l'aper Series, Working Paper No. 2010-05, 2010), available at httpi//papers.ssm.com/sol3/papers.cfm? abstract id $=1564230$ (stating that prior to Qualitex Co. v. Jacobson Prods. Co, 514 U.S. 159 (1995) only 93 nontraditional trademarks had been recorded). 
there have been 688 trademark applications for nontraditional trademarks (excluding product configuration or product packaging, the original justification for Section $43(a)^{.3}$ Of course, relying on the word "device" for these purposes is historically inaccurate. It has reached such a bizarre extent that one person was even encouraged to apply to register his own DNA sequence. ${ }^{74}$

\section{Moral rights}

Much is made of the moral right in the world of copyright. Much more is made of whether the United States should or does comply with its treaty obligations under the Berne Convention that mandates the protection of some moral rights. ${ }^{\text {i5 }}$ The protection of moral rights as such fundamentally sets the Civil Law apart from the Common Law of copyright. ${ }^{76}$ Moral rights include rights of attribution, integrity, divulgation and withdrawal. ${ }^{7}$
In countries that recognize moral rights, for example, it is a violation of the moral right of integrity to colorize motion pictures if the original author objects. One way of expressing this difference is that the Civil Law recognizes the personality ${ }^{78}$ of a work, while the Common Law only recognizes an economic interest in the work. ${ }^{79}$

Although the moral right was originally saved for individuals and not corporations, some countries, such as Japan, consider a corporation a juridical person and, as such, recognize a corporation's ability to maintain and enforce moral rights. ${ }^{8} \mathrm{As}$ such, it is not inconsistent to express a corporation as an owner of the moral right of trademark.

This distinction in copyright between Civil Law nations such as France and Japan compared to the United States is quite remarkable. It leads to many international disputes regarding the appropriate scope of the copyright. ${ }^{81}$

73 See id. at Appendix E. After Qualitex Co. V. jacobson l'rods. Co., 514 U.S. 159 (1995), the average nontradilional trademark regis Irations went from less than 2 per year to nearly 50 per year. Despile this increase, nontraditional trademarks still onjy comprise less than $2 / 100$ th of a percent of the total trademark applicaitons. See id. al 4. See also Nick Pisarsky, NoTE PoTAYio-PoTAlfo-Lef's Call the Whole Thing Off: Trotemark Prolection of Product Sounds, 40 CoNiv. L. REv. 797, $803 n .28$ (2008) (showing that the percent of nontraditional trademarks tlat cannot be perceived visually was $0.00727 \%$ ).

74 Registration No. 76016924 (fiked Apr. 3, 2000; abandoned Jan. 21, 2002). See also Frank "Dr. Future" Ogder's website available at littp://www.drtomorrowcom/feature/straightgoods.himl (last visited Sept. 15, 2010) (stating his belief that registering his DNA gene sequence as a trademark is necessary to prevent "reproduction including the production of humans, clones, survival machines, or futuristic animals").

75 Kimberly Y. W. Hoist, A Case of Bad Credit? The United States and the Protection of Moral Rights in Intellectual Property Law, 3 Burs:

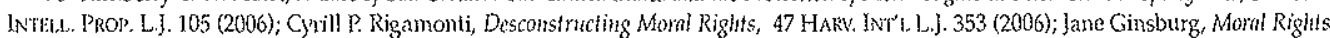
in a Common law System, in MORA. Rughts Protrction in A Coprright SYSTEM 18 (Peter Anderson \& David Saunders eds., 1992),

76 Sheldon Halpern, Of Mornl Right and Moral Righteotsness, 1 MakQ. INTUL.. Prop. L. REV, 65 (1997).

77 MLAHAE B. NMMMER \& DAVB NIMMER, NMMER ON COPYRIGT, \& 8D.01.

$78 \mathrm{I}$ do not inkend nor do I llink it necessary to take sides in the debate regarding whether the moral riglt should be protected separately from (he copyright laws of any jurisdiction (dualist view) or whether liey should or are best conceived of as part of the copyright regime of any jurisdiction (monist view). I am merely making the general claim that moral rights protect the personality of a work and that trademarks in the Uniled States lave taken on a personality that Congress at least seems lo think is worthy of protection. See generally, Cyrill P. Rigamonti, 7he Concephnt Tmonformation of Moral Rights, 55 AM. J. Comp. L. 67, 73.76 (2007).

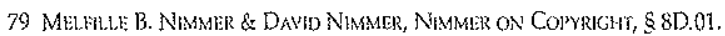

80 Konami, K.K. v. lcluro Komami, 1696 Hanrei jiho 145 (Tokyo D. Ct. A.ug. 30, 1999).

81 Monica Kilian, A Hollow Viclony for the Common Law? Thips and the Moral Rights Exchusion, 2 J. Makshald, Rev. INteu. Prop. L. 321, 322 (2003) ("The continued squabble over moral rights between common law and civil law countries is a stumbling block for harmonization of international copyright laws."). 
A similar distinction exists in trademark between Civil Law countries and the United States. The trademark right in Civil Law countries is usually justified as a property right. ${ }^{s 2}$ It is accepted that the trademark is subject to property ownership. Conversely, in the United States, the trademark jurisprudence heretofore has been recognized as a right of exclusion based merely on priority of appropriation. $^{83}$ One owns the right to exclude others from marks which one has priority to, but does not own the mark itself. ${ }^{84}$

As I predicted it would in $1994,{ }^{85}$ the concept of dilution has driven a major seachange in American trademark jurisprudence. The trademark right in the United States has slowly come to be far more similar to the nature and extent of moral right protection, rather than the mere right to exclude. Now, the United States recognizes the personality of a trademark and the Civil Law nations continue to recognize it as an economic right. The significance is that, once again, the Civil Law and the United States do not share an understanding of what a trademark right confers. Therefore, the basis jurisprudence of American trademark law and that of the Civil Law remains disparate.
The moral rights doctrine is a very broad idea that is said to protect the "personality" of a work. "This doctrine gives the author the right to claim authorship of a work (right of attribution or right of paternity); the right to object to changes, modifications, or bastardizations of the a work (right of integrity); the right share or not share a work with the public (right of divulgation); and the right to remove a work from the public after publication (right of withdrawal). ${ }^{87}$ Moral rights protect the "personal, intellectual, and spiritual interests of the author." ${ }^{\prime \prime s}$ The notion is that the author merges him or herself with the work and as such the work becomes part of their personality. As such, just as one may not sell part of your body, one cannot alienate a moral or personal right in a work. My contention here is that as the trademark grows in strength and stature, lower courts and the United States Congress have come to protect the mark as a personality worthy of protection as if it were a work of the creator.

As the United States trademark right expands in scope, this notion can apply to describe the functioning of the United States trademark right. Although the moral right is inalienable in most coun-

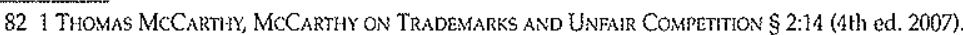

83 The Trademark Cases, 100 U.S. 82, 94 (1879)("At common haw the exclusive right to it grows out of ils use, and not its mere adoption. By the act of Congress this exclusive right atlaches upon registration. But in neither case does it depend upon novelty, invention, discovery, or any work of the brain. It requires no fancy or imagination, no genius, no laborious thouglit. It is simply founded on priority of appropriation.") For an excellent review of this debate, see Simone A. Rose, Will Allas Shrug? Dilution Protection for "Famus" Trademarks: Anti-Competitize "Monopoly" or Eaned "Property" Right?, 47 FL.A. L. Rrv. 653 (1995). See, also, David S. Welkowit,

Reexamining Trademark Dilution, 44 VANO. L. Rev. 531 (1991); Milton W. Handler, Are State Antidilation Laws Compatible with the National Protection of Trademarks?, 75 TrademarK REP. 269,271 (1985).

84 United Drug Co. v Theodore Rectanus Co., 248 U.S. 90,97 (1918)("There is no such thing as property in a trade-mark except as a right appurtenant to an established business or trade in comection with which the mark is employed. The law of trade-marks is but a part of the broader law of unfair competition; the right to a parlicular nark grows ont of its use, not its mere adoption; its lunction is simply to designate the goods as the product of a particular trader and to protect his good will against the sale of another's product as his; and it is not the subject of property except in connection with an existing business.")

85 That a trademark dilution statute would create a copyight in trademarks that protect even the idea of a trademark, is precisely what lias happened.

86 "Work" is the term for the object of copyright protection.

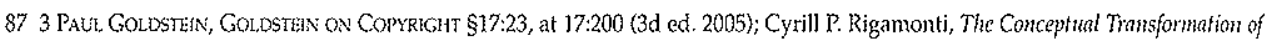
Mornl Rights,55 AM. 3. COMP. L. 67,70 (2007). The rights of divulgation and withdrawal and not relevant to this discussion.

88 Adolf Dietz, Alai Congress; Antwerp 1993: The Moral Right of the Aufhor: Moral Rights and the Civil Law Countries, 19 COLUM.-VLA J.L. \& ARTS 199, 207 (1995). 
tries that recognize the moral right ${ }^{\text {s9 }}$ and, of course, the United States trademark is completely alienable, moral rights actually do describe the United States trademark right as to the immediate holder of that right, whether an original creator or an assignee.

A member of the Berne Convention is mandated to provide protection for two of these moral rights (attribution and integrity $)^{\infty}$ and most Civil Law countries do. There is great debate about whether or not the United States in compliance with this requirement even though it ratified the Berne convention in 1989."

The phrase droit moral ("moral right") was first used as a legal term of art by the prominent French jurist Andre Morillot in 1878. ${ }^{92}$ In Cinquin c. Lecocq," before the Cour de Cassation, Morillot asserted that the property rights of an artistic work under copyright was not community property between spouses, but rather belonged solely to the creator. ${ }^{94}$ This con- cept grew out of the philosophy of individualism that thrived in France following the French Revolution.95 Although the court disagreed, the court did recognize that the artist-husband alone possessed distinct moral rights over his creation. .6

Following this acknowledgment, European courts struggled over which two German philosophies to adopt: Immanuel Kant's monist system or Georg Wilhelm Freidrich Hegel's dualist system." Kant's model revolved around the concept that a work of art is not merely an external object, but rather is an expression of the creator's personality. ${ }^{98}$ Hegel's conception differed in his belief that the work itself is necessary for the manifestation of the artist's personality; therefore the artistic work is property to which the artist's personality is inseparably attached. ${ }^{9}$ In the early 1900's, German Jurist Joseph Kohler further developed Hegel's theories defining how an economic right in the artistic creation may simultaneously co-exist with

89 Id, at 208; Edward J. Damich, The Right of Personality: A Common-lnw Basis for the Prolection of the Mornl Rights of Authors, $23 \mathrm{GA}$. L. REv. 1, 14 (1988).

90 Berne Convention for the Protection of Literary and Artistic Works, art. 6bis (Sept 9, 1886; revised July 241974 and amended 1979; entered into force for the U.S. Mar: 1, 1989 (Sen. Treaty Doc. 99-127)) U.S.T. Lexis 160 or 1 B.D.I.E.L. 715

91 Elizabeth Dillinger, Mulinting Picasso: The Case For Amouding the Visual Artists Rights Act io Pronde Protection of Mord Rights After Denth, 75 UMKCL. REV. 897, 906-07 (2007) ("IW]e may not be intellectually honest when we conclude that we can join Berne by deeming U.S. laws to be in compliance...") (quoting 134 Cong. Rec. H3079 (daily ed. May 10, 1988) (statement of Rep. Berman)). William Belanger, Article: U.S. Compliance with the Berne Combention, 3 Gro. MAsON IND. L. REv. 373, 390 (1995) ("Some commentators have suggested that full compliance with the Berne Convention would potentially violate the Constitution.").

92 Edward J. Damicl, The Right of Personnlity: A Common-law Basis for the Protection of the Moral Rights of Authors, 23 GA. L. REv. 1, 29 (1988); Cherly Swack, Safegunting Att istic Creation and the Cultural Heritage: A Comparison of Droit Moral Between France and the Uniled States, 22 Colum.-VLA J.L. \& ARrs 361, 373 (1998).

93 Civ., June 25, 1902, D.P. 1903.15.

94 Willan Strauss, Mord Rights of the Author, 4 AM. J. COM1. L. 506, 513 n.31 (1955).

95 Laura Lee Van Veizen, injecting a Dose of Duty imto the Doctme of Droit Moral, 74 lowa L. Rev. 629, 632-33 (1989); DaSilva, Droil Moral and the Amoral Copyright: A Comprison of Attists' Rights in France and the United States, 28 BuLL. CoryriGHT SOC'Y U.S.A. 1, 9 (1980),

96 Edward Damich, The Right of Personality: A Common Law Basis for the Protection of the Morn Rights of Authors, 23 GA. L. REv. 1, 29 (1988).

97 DaSiva, Droil Moral and the Amoral Copyright: A Comparison of Artsis' Rights in France and the United States, 28 Butl. Conreicht SOC'Y U.S.A. 1, 12 n.85 (1980).

98 Cherly Swack, Snfeguarding Artistic Crention and the Cuhural Heritage: A Comparison of Drot Moral Beturen France and the United States, 22 Coum.VLA).L. \& ARTs $361,370-71$ (1998).

99 Id. at 37 . 
the personal rights in its creator..$^{100}$ Morillot argued under the dualist concept, and after court's decision in Cinquin C. Lecocq this notion prevailed in France. ${ }^{108}$

Some moral rights scholars would dismiss the argument that trademarks in the United States have become subject to protection akin to moral rights out of hand. ${ }^{102}$ However, those who dismiss are talking about what trademark jurisprudence formerly was or what it ought to be, not what it has become.

\section{A. Attribution}

The moral right of attribution is "perhaps the most important moral right." "103 The right of attribution allows an author to claim a work as their own. This claim gives an author the ability to object, essentially, to a likelihood of confusion ${ }^{104}$ over the source of a work. In Europe, this is known as the right of paternity. ${ }^{105}$ It allows an author to claim or not claim that he/she is the author of any given work.

This is most analogous to the source denoting function in trademarks. The source denoting function tells a purchaser from where a product emanates. In fact, "[i]t is the source-denoting function that trademark laws protect, and nothing more." ${ }^{\prime \prime 6}$ As we shall see, the American trademark right has come to protect far more than the mere source denoting capacity of the trademark.

The right of attribution first had roots in ancient Rome, which recognized the growing problem of plagiarism. ${ }^{107}$ To provide relief to the angry authors, a cause of action known as plagium, meaning "the crime of stealing a human being" was created in the first century A.D. ${ }^{108}$ As the Roman Empire declined and Europe plunged into the dark ages, these concepts bowed to the authority of the Catholic Church, which gave little or no attribution to individual artists. ${ }^{109}$ It wasn't until the Renaissance era when these rights began to reappear."

In 1498 Michelangelo Buonarroti was commissioned by a French cardinal to create La Pietà, depicting the body of Jesus on the lap of his mother Mary after the Crucifixion, as a tomb monument in the chapel of St. Maria della Febbre in St.

100 Id. at 372.

101 Natalie C. Suhl, Note, Moral Rights Protetion in the United Shates Under the Beme Convention: A Fictional Work?, 12 ForotiaM INTELL. PROP. MEDA \& ENT. L.J. 1203, 1211-12 (2002).

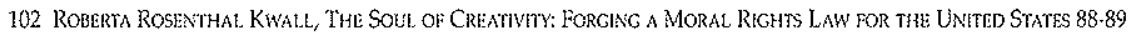
(2010) "Trademark law is concerned with preventing consumer confusion, a concept totally unrelated to the authorial interests encompassed by moral rights." $)$.

103 Cyrill P. Rigamonti, Deconstricting Moral Rights, 47 HARv. JN'L. L.). 353, 364 (2006).

104 Robert C. Bird, Moral Rights: Dingnosis and Rehabilitation, 46 AM. Bus. L.J. 407, 440 (2009).

105 Dan L. Burk, Copyright and Feminism in Digital Media, 14 Am. U. J. Gender SOC. Pol'Y \& L. 519, 545-547 (2006).

106 Anti-Monopoly he. v. Gen. Mills Fun Group, 611 F.2d 296, 301 (9th Cir. 1979).

107 Bird, supra note 102 , al 413.

108 See Cheryl Swack, Safegunding Artistic Creation and the Culturnl Herilage: A Comporison of Droit Moral Between France and the Unitcd Siates, 22 Colum.-VLA I.L. \& ARTS 361, 367-68 (1998).

109 Alicia Maria LaTores, Luca della Robbia as Maiolica Producer: Artists and Artisans in fifteenth-Century Florence, (May 5, 2009) (Wheaton College), available at http://dspacenitle.org/bitstream/handle/10090/8394/latores\%20-\%20thesis\%20-\%2009.pd?? sequence $=1$.

110 See Natalie C. Suhl, Note, Moral Rights Protection in the United States Under the Berne Convention: A Fictional Work?, 12 FOROHAM INTELL. I'ROR. MEDIA \& ENT. L.J. 1203, 1206 (2002) 
Peter's Basilica. The work was instantly recognized as one of the greatest sculp. tures ever created, but when a group of locals crowded in admiration, Michelangelo overheard one of them credit the work to Cristoforo Solari, another sculptor." That night, under the cover of darkness, Michelangelo crept back into the church and asserted his right of attribution by carving MICHAELA[N]GELUS BONAROTUS FLORENTIN[US] FACIEBAIT] ("Michelangelo Buonarroti, Florentine, made this") on the sash rumning across Mary's chest.". This was the only work he ever signed." ${ }^{13}$

The trademark right of source denoting has become analogous to the moral right of attribution. Today, when trademark users apply their marks to their goods or services, trademark jurisprudence supports their claim as if it were carved in stone. Source denoting has become much more signficant than merely letting consumers know from where a product eminates. Now, a famous mark can exclude all uses of noncompeting marks that do no confuse. Now, a holder of a trademark can prevent its registration as a domain name even if there is no confusion. Since the inception of incontestability, the holder of an incontestable mark may prevent others from using it even if it merely descriptive and therefore no trademark at all. In this way, holders of trademarks have come to hold something that seems akin to the moral right of attribution for their marks.

\section{B. Integrity}

The moral right of integrity protects a copyrighted work from change or mutilation. This gives authors the exclusive right to display their work in the original form and protects against any distortion of that original expression. ${ }^{114}$ "To deform his work is to present him to the public as the creator of a work not his own, and thus makes him subject to criticism for work he has not done."

The best example of the right of integrity in operation is the battle over the colorization of movies. When a French television station, La Cinq, gained purported rights (from an assignee of the copyrights) to colorize John Huston's The Asphalt Jungle, his heirs filed suit claiming a violation of their father's moral right of integrity. ${ }^{16}$ Although Huston's heirs lost the case at the lower court because the court found that the television company did not colorize the original copy of the movie, ${ }^{117}$ the French Supreme Court reversed and found Huston's right of integrity infringed because Huston had created the movie. ${ }^{118}$ The Court ordered some

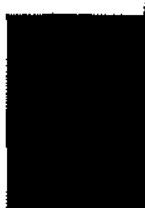

111 WILLIAM E. WALLACE, LIHE AND EARLY WORKS, 223 (Routledge 1995).

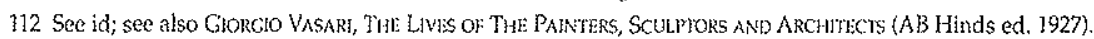

113 Aileen June Wang, Michelangelo's Signaine, The Sixtenth Century jomm, Vol. 35, No. 2, 447-473 (2004) available at litp://www.jstor.org/stable/20476944.

114 Leslie Kim Treiger-Bar-Am, The Moral Right of Integrity: A Fredom of Expression, in 2 Naw DiRECrons IN CorrRicht 150 (Fiona Macmillan ed, 2006).

115 Martin A. Roeder, The Dochine of Mornl Right, 53 Harv. L. REv. 554,569 (1940).

116 Cass. 1e civ, May 28, 1991, R.I.D.A. 1991, 149, 197.

117 Id. The lower courl also refused to grant relief claiming that Huston signed away his atthorship riglats in a contracl with the film producer valid under American Law. Alexander Gigante, Ice Patch on the Information Supenighwy: Foreign Liability for Domestically Crented Comtent, 14 CARDOZO ARTS \& ENT. L.J. 523, 535 (1996).

118 Cass. 1e civ., Dec. 19, 1994, R.I.D.A. 1995, 164, 389. This would not have been the outcome in the Uniled States as there is no protection for someone like fohn Houslon who did not own the copyright to his work. jimmy A. Frazier, Comment, On Moral Rights, Artist-

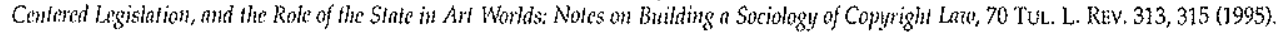


$\$ 100,000$ in damages to be paid to the Huston heirs and that the colorized film. be destroyed."1"

The right of integrity is very analogous to the dilution prevention right in trademark law. ${ }^{120}$ For example, a Paris District Court prohibited a director from putting on the play, Waiting for Godot, casting all actresses because it interfered with the playwright's intention that the roles be played by men. ${ }^{121}$ The court's decision was grounded in the desire to protect the playwright's moral right of integrity which would have been violated had the director tainted the nature of the play by using all actresses. ${ }^{122}$

Also, an Indian court found that the destruction of a publically recognized sculpture amounted to mutilation of the sculptural work and consequently a violation of his moral right of integrity regardless of the location at which the destruction took place. ${ }^{123}$

The right of integrity is very analogous to the dilution right in the United States. Now, selling Kodak brand pianos violates the integrity of the famous Kodak brand.
The mere fact that another Kodak is on the market lessens the capacity of Kodak to distinguish itself in the minds of potential consumers, just as a moral right artist has the right to protect the integrity of his/her work. Buick brand aspirin, we are told in the legislative history, dilutes the famous mark for an automobile. If Buick can prevent a third party from naming their aspirin "BUICK", far more is going on than the right of exclusion. Here, it is only theoretically justified if one accepts that the automobile manufacturer's right of integrity is being violated. That is, the very integrity of the aura surrounding the mark BUICK is destroyed. When the association is made with aspirin, the former distinctiveness of the mark BUICK is lessened (or destroyed). To allow the owner of BUICK to prevent this destruction allows that entity the right to prevent damage to the integrity of the mark.

As such, the trademark BUICK is now protected as if it were appropriate subject matter of the moral right of integrity.

119 The Huston heirs were awarded $\$ 74,000$ from Turner Entertainment and $\$ 37,000$ from France's Channel 5 . Finm Find for Colorizing 'Iungle', RocKY MNT. NEws, Dec. 29, 1994 at 16D.

120 Bird, supra note 102 , at 439 .

121 Tribunal de grande instance [T.G.1.] fordinary court of original jurisdiction] Paris, 3 e ch., Oct. 15, 1992, R.J.D.A. 1993, 155, 225; See Jean-Luc Piotraut, An Authors' Rights-Based Copyright Lnw: The Fainess and Morality of French and American Law Compared, 24 CARDOZO ARTS \& ENT. L.J. 549, 605 (2006).

122 Although this action was brought by the estate of playwright Samuel Beckett, during his lifelime he denied all requests for permission to deviate from the all male cast except one. The only exception was for Frau Osterkamp who wanted to use a female cast for a production at the 1982 Berlin Festival. Beckett's authorization was conditioned on the audience's understanding of his complete disapproval of the modification. Later in 1988, a Dutch theater produced the play with a female cast and withoul Beckett's permission. When Beckett pursued legal action in the Netherlands, the judge ruled in favor of mixed gender casting and found the play to have been true to its original form despite including women. Outraged at this result, Beckett bamned production of all of his plays in the Netherlands and amended lis contracts with other countries to disallow any modifications to the play or the stage directions. See Willam Hutchings, Samuel Backem's Wattig for Godot. A Rererence Guide 93 (Praeger Publishers 2005).

123 In addition to the artisl's moral right of integrily, the court held that mutilation of the sculplure violated the integrity of the piece in relation to Indian culture because the sculpture had becone a public emblem of Indian heritage. Sehgal v. Union of India (2010) 39 R.S.R 830 (2005). 


\section{Tension between the Courts and the Congress on Trademark Jurisprudence}

\section{A. Dilution}

Primarily at the Supreme Court level, there has been much tension between the Court and Congress as to the scope of the trademark. The best example of this is the Victoria's Secret case. ${ }^{124}$ In that case, the Supreme Court held that a claimant of dilution had to show that its mark was "actually diluted," a "likelihood of dilution" was not enough. ${ }^{125}$ Without saying what precisely (other than a presumption that absolute identical marks would be enough) ${ }^{126}$ constituted "actual dilution," the Court changed the analysis of when a trademark right was harmed. Up to that point, the test had always been a "likeli- hood" of infringement. To change this to a requirement that the claimant had to show evidence of actual harm, when the alleged harm from dilution is remarkably speculative at best, was to nearly extinguish the cause of action. In the reported cases, after the Victoria Secret case, the number of cases plummeted. ${ }^{127}$

However, Congress, at the behest of Limited Brands, Inc., Victoria's Secret' PAC and Jack Valenti, ${ }^{20}$ the most influential lobbyist in the 2006 election year, expressly overruled the Supreme Court in the Trademark Dilution Revision Act (TDRA) of 2006.129 According to the TDRA, the appropriate standard of when a mark is diluted is now a "likelihood of dilution."

Not surprisingly, the number of cases based on a dilution claim has rebounded..$^{3 .}$

124 Moseley v. V Secret Cataiogue, 537 U.S. 418 (2003). In the opinion the court went out of its way to hint that "expansion of trademark law beyond its usual boundaries was not the product of a careful legislative process that considered its elfect on other intellectual property regimes." David S. Welkowitz, The Sipreme Conm and Tratemark Law in the New Milleminm, 30 Wm. MutCHLL. L. Rev. 1659,1700 (2004). See Mostey, 537 U.S. at 429 ("Unlike traditional infringement law, the prohibitions against trademark dilution are not the product of common-law development, and are not motivated by an interest in protecting consumers."). The opinion goes on to discuss how dilution was first considered in 1988, but was deleted for concerns of non-compalibility with the First Amendment. When the dilution was finally added in 1995 , the hearing was limited to a single tay and no opposition to the bill was raised. Id. at 431 .

125 Id. at 433 (stating that ambiguity within 15 U.S.C. $\$ \$ 1125$ (c)(1), 1127 confirmed "the [Supreme Court's] conclusion that aclual dilution must be established.").

126 Id. at 434 ("[D]irect evidence of dilution such as consumer surveys will not be necessary if actual dilution can reliably be proven through circumstantial evidence - the obvious case is one where the junior and senior marks are identical."). "[M]enta] associalion will not necessarily reduce the capacity of the famous mark. ..." Id.

127 See Marc L. Delflache, Sarah Silbert, Cluristina Hillson, Article: Life After Moseley: The Trademark Dilution Revision Act, 16 TEx. INTEL. PROP. L. . 125, 149-50 (2007) (stating that in the late 1990s there was a nearly $100 \%$ increase in trademark dilution lawsuits; after Moseley it became nucl more difficult for mark owners to prove dilulion). Between 1997 and 2003, there was an average of twentyfour federal dilution cases per year. Following Moseley, but prior to the Trademark Dilution Revision Act of 2006, the number of federal dilution lawsuts diopped to an avernge of just 8.5 per year. See The Whinm Mitchell Study on Trndemark Litigation, available at http://wwwwmilchell.edu/intellectual-property/Milchell-Study-on-Prademark-Litigation/.

128 See Michael A. Carrier, Cobining hicherhal Property Throngh a Proprery Parndigm, 54 Dukn L.). 1, 11 n. 15 (2004) (discussing Jack Valenti's role in the "propertization" of intellectual property); Erika Overby, A Nation of Whinps: the Politics of Dilulion Law (student paper on sile with the author).

129 Pub. L. No. $109-312, \S 2,120$ Stat. 1730,1730 (codified at 15 U.S.C. $\$ 1125(\mathrm{c})(2006)$ ).

130 Louis Vuitton Malletier S.A. v. Haute Diggity Dog, LICC, 507 F.3d 252, 264 n.2 (4th Cir: 2007) ("Congress amended the [TRDA] principally to overrule Moseley and to require that only a likelihood of dilution need be proved."). See also V Secre Catalogue, Inc. v. Moseley, 605 F.3d 382 (6th Cir. 2010) ((affirming summary judgment for Victoria's Secret; after twelve years in the legal system, finally the case is closed). "The provisions of the Trademark Dilution Revision Acl of 2006, 15 U.S.C.5. \$ 1125(c), change the test for dilution by tarnishment from an 'nctual' to only a likelihood of 'tarm' to the 'reputation' of the serior mark." ld. at 385 n. .

131 By 2007 the number of federal dilution lawsuits nearly tripled, going from an average of 8.5 cases to lwenty-one cases per year. See The William Mitchell Study on Thademork Litigation, available at littp:/ www.wmitchell.edu/intellectual-property/Mitchell-Study-onTrademark-Litigation/. 


\section{B. Fair Use}

In KP Permanent Makeup v. Lasting Impressions I, Inc., ${ }^{132}$ the Supreme Court attempted to further restrict the expansion of the trademark right. There, the Court held that fair use (and therefore a finding of non-infringement) consisted of conduct where a third party used a descriptive mark descriptively. ${ }^{133}$ If this happened, there would be no infringement and the defendant would not be required to make a showing of a lack of confusion. ${ }^{134}$

The fair use doctrine is yet to be countered by Congress. Perhaps they agree; perhaps there are more important issues on their plate. Regardless, the fair use doctrine may operate to provide the brake to the expansion of trademark jurisprudence that is required if we are to maintain balance between trademark holders and consumers. ${ }^{135}$

\section{Courts Resist; Congress Favors}

Historically, lower courts were hesitant to expand trademark jurisprudence in the United States to the extent that Congress seemed to require.

In Mead Data Central, Inc. v. Toyota Motor Sales, U.S.A., Inc., ${ }^{136}$ the Second Circuit overturned a finding of dilution because the marks LEXUS and LEXIS were not similar enough. ${ }^{137}$ In Fruit of the Loom, Inc. v. Girouard, ${ }^{135}$ the Ninth Circuit refused to find a violation of the dilution act because FRUIT OF THE LOOM was not famous enough. ${ }^{39}$

Over the 60 history of the Lanham Act, the total number cases that were reported peeked in 2002 at 101 cases. By 2006, this number had dropped to 53.141 The amounts of total damages and total attorney fees awarded has continued to decline since $2000^{142}$ even though the total number

132 543 U.S. 111 (2004).

133 Although Lasting Impression I, Inc. had obtained incontestability on its tradenark consisting of the words "Micro Colors," relying on 15 U.S.C. \$1115(b)(4), KP Permanent Make-Up, Inc. ("KP") maintained that their use of the same words in an advertisement did not constitute infringement because the words were necessary to accurately describe their product. The Supreme Court agreed with KP, ruling that such a use is fair. Id. at 114-15. See Sue Ann Mota, Arficle: KP Permanen Make-Up v. Lasting Impression-The Stntutory Defense of Fair Use is Avnilable in Tradenark Infringement Cases Wilhout Negating the Likelihood of Consumer Confusion, According to the Supreme Cowt, 39 VAl. U.L. R.v. 327, 335 (2004) ("IThe Lanham Act was not meant to deprive commercial speakers of the ordinary use of descriplive words.").

134. "A] plaintiff claiming infringement of an incontestable mark musl show" likelihood of consumer confusion as part of the prima facie case ... the defendant has no independent burden to negate the likelihood of any confusion in raising the affirmative defense that a term is used descriplively, not as a mark, fairly, and in good faith. ..." KP Permanent Make-Up, 543 U.S. at 124. Naturally, it is only after the plaintiff has made a prima facie showing that a defendant has a need for an affirmative defense. Id. at 120 . Requiring the defendant to prove that the plaintiff cannot prove a required element prior to qualifying for the statutory defense is no defense at all, and simply "would make no sense." It. Therefore, the court reasoned that there was no other logical way to interpret 15 U.S.C. $\S 1115(b)(4)$. Id.

135 David S. Welkowitz, The Stupreme Court and Trademark low in the New Millomium, 30 WM. Murchnd, L. REv. 1659, 1700 (2004) ("T The Court may be signaling that there are limits to Congress's power to regulate these areas under the Commerce Clause, as opposed to the Patent and Copyright Clause.").

136875 F.2d 1026 (2d Cir. 1989).

137 See id. at 1031 ("t)Dilution theory presumes some kind of mental association in the reasomable buyer's mind between the two parties' uses of the mark'... However, if a mark circulates only in a limited market, it is unlikely to be associated generally with the

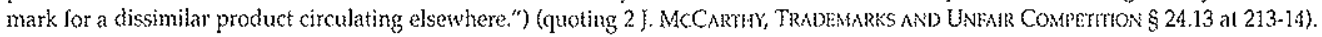

138994 l:2d 1359, 1363 (9th Cir.1993).

139 ld. (finding that the Defendant's thongs and "bustiers" adorned with plastic fruit and whimsically named "fruit flops" and "fruit cups," did not dilute the "Fruit of the Loom" mark). The generic term "fruit" alone is not famous enougl to warrant protection. "Truit of the Lom" gets its special force from the combination of the words "fruit" and "loom" used together. Id. at 1362.

140 See The Willin Mitchell College of Law Study on Tradenatk Litigation, Graph A: Total Number of Reported Cases per Year, http:/ www wmitchell.edu/intellectual-properly/files/WM-TMStudy-GraphA.pdf (last visited Aug. 2, 2010) [hereinafler Graph A]

$141 \mathrm{ld}$.

142 See Kenneth L. Port, Tradenark Extortion: The Eud of Trademark Law, 65 WASH \& L.FE L. REv. 585, 622-24 (2008) (hereinafter Port, Trademark Exfortion] (interpreting the data collected by the William Mitchell Study on the number of cases reported). 
of cases filed continues to increase. ${ }^{143}$ Although I have posited that the reason for this precipitous decline may be the fact that trademark owners are being over aggressive in filing law suits and thereby leading to many settlements, ${ }^{1,4}$ it may also be that the plaintiffs are settling the claims because they lack confidence in a litigated outcome. One way or the other, the data indicates that most cases end in a settlement. Only $1.3 \%$ of all filed cases end in a trial on the merits. ${ }^{155}$ Perhaps the reason for such a high volume of filed claims and a low volume of fully litigated claims is uncertainty by both sides regarding what the precise parameters are of American trademark jurisprudence.

Of course, the tension between the Supreme Court and Congress regarding trademark jurisprudence is rather obvious. There have been many cases from Supreme Court in the last two decades. After culminating in the high water mark of Two Pesos, Inc. v. Taco Cabana, Inc. ${ }^{\text {no }}$ in 1992 and Qualitex Co. v. Jacobson
Products Co. Inc.197 in 1995, there has been a clear retrenchment of the expansion of trademark rights by the Supreme Court. ${ }^{\text {14 }}$

First, in Wal-Mart Stores, Inc. v. Samara Brothers, Inc. ${ }^{149}$ in 2000, Wal-mart had intentionally and specifically usurped Samara's design for children's clothing. Wal-mart sent pictures of Samara's clothing to its designer in the Philippines with instructions to copy it. ${ }^{150}$ In many of the pictures, Samara's label was visible and Samara's trademark was apparent. ${ }^{15}$ Yet, the Court found that the Lanham Act was not infringed because Samara's clothing had not attained a secondary meaning in the market place. ${ }^{152}$ The Court dismissed Samara's claim in a short, 11 page opinion and created new categories for trade dress protection. They determined that there were three types of trade dress: product design, product packaging, and a tertium quid. ${ }^{153}$ As Samara's claim was categorized as product design, they were required to show secondary meaning where product packaging is protected without secondary

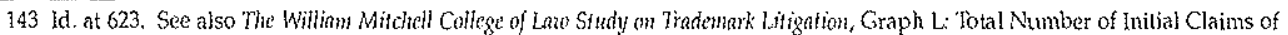
Infringement per' Y'ear, http://www wmitchell.edu/intellectual-property/files/WM-TMStudy-GraphL.pdf (last visited Aug. 2, 2010),

144 See Porl, Thatonark Exiortion, supra note 342 , at 633 (ciling trademark extortion as the reason why the mumber of claims is rising while the damages awarded by the courts steadily decieases). Findemark exlortion is the filing of a case that may not succeed on its merits with the goal of reaching an out of court settlement. Id.

$145 \mathrm{Jd}$ at 628 . See also id. at 622 (noting that on average, al trial, trademark holders have roughly a $55 \%$ chance of obtaining an injunction, and only about a $5.5 \%$ chance of receiving damages).

146505 U.S. $763(1992)$.

147514 U.S. 159 (1995)

148 Sheldon W. Halpern, Trafficking in Trademarks: Sething Bowndaries for the Unensy Relationship Betaten "Propery Rights" and Thademark nud Publicily Rights, 58 DEPAUL. L. REv. 1013, 1019-20 (2009) (stating that generaily the five Supreme Count trademark opinions in the last decade, and specifically Wal-mant and TrafFix, "attempt to inhibit the prospect of trademark law impinging on the boundaries and bimitations of patenl laws...").

349529 U.S. 205 (2000).

150 Id. at 207. The designer/manufacturer, Judy-Philippine, Hnc, copied a total of 16 of Samara's garments with only minor modifications in the design. In 1996, Wal-Mart sold the knockoffs at a lower price than that of Samara (whose producl line was featured in JC Penney), generating more lhan $\$ 1.15$ million in gross profits. Id.

151 Samara Bros. v. Wal-Mart Stores, Inc., 165 F:3d 120, 122 (2d Cir. 1998).

152 Wal-Mart Stores, lnc, 529 U.S. at 213.

153 ld at 215 (explaining that allhough Two Pesos, inc. v. Taco Cabana, Inc., 505 U.S. 763 (1992) established that trade dress can be liejd as distinctive without secondary meaning, Taco Cabana's trade dress differed from Samara's because the decor of a restaunant is either product packaging or fertinm quid (i.e., the decor camnot be classified exclusively as either design or packaging). 
meaning. ${ }^{154}$ The tertium quid doesn't stand up to any sophisticated analysis.

Next, in TrafFix Devices Inc v. Marketing Displays Inc., ${ }^{155}$ in 2001, the Supreme Court held that road-side signs with spring loaded legs so they would stand up in the wind were functional and therefore not protectable trade dress. The Court held that the claimed trade dress was function because it was "essential to the use or purpose of the article." 156 Through the functionality doctrine, the Supreme Court greatly restricted the expansion of the trademark right.

In Dastar Corp. v. Twentieth Century Fox Film Corp. ${ }^{157}$ the Court found that Section 43(a) of the Lanham Act could not operate as an alternative to copyright protection even though the plaintiff could establish that it was the successor in interest to the actual source of the video. ${ }^{158}$

In Moseley v. V Secret Catalogue, Inc., ${ }^{159}$ also in 2003, the Supreme Court held that the appropriate standard for a finding of trademark dilution was "actual dilution" rather than the far lesser standard of a "likelihood" of dilution. The Court resolved a debate regarding interpretation of the Lanham Act and whether the stan- dard for dilution should be the same as the standard for infringement. The Court elected to use the higher standard and require actual harm to be show whether than a merely likelihood, the standard for infringement.

Finally, in 2004, in KP Permanent MakeUp, Inc. v. Lasting Impression I, Inc., ${ }^{160}$ the Court again restricted the trademark right at issue and determined that a registered trademark that was descriptive had to endure other fair uses of that mark so long as they amounted to a descriptive mark being used descriptively.

Therefore, put in this light, it is clear that the Supreme Court in the last decade has been attempting to reign in the trademark right.

In the mean time, Congress continues to expand trademark jurisprudence. Congress passed first the ITU statute, where a party's mere intent to use a mark can be preserved for three years. ${ }^{161}$ Congress passed the original dilution statute $^{162}$ and then the Trademark Dilution Revision Act ${ }^{163}$ which expressly overruled the Victoria's Secret case. ${ }^{\text {tot }}$ Congress created the ACPA, ${ }^{165}$ allowing, for the first time in American history,

154 Id. at 216 . See also id, at 213 . ("In the case of product design ... we think consumer predisposition to equate the feature with the source does not exist. ... Consumers should not be deprived of the benefits of compelition with regard to the utilitarian and esthetic purposes that producl design ordinarily serves...")

155532 U.S. 23 (2001).

156 Id. at 32 (quoting hinood Laboratories, Enc. v. Ives Laboratories, Mnc., 456 U.S. 844, 850, n.10 (1982)).

157539 U.S. 23 (2003).

$158 \mathrm{See} \mathrm{id}$ at 37 (explaining that if the Lambam Act were interpreted to include protection of the originators of the video, rather than just those who produce reploductions of it for sale, $\S 43($ a) would allow perpetual patents and copyrights - which is prolibited by congress).

159537 U.S. 418 (2003). See simm text accompanying notes $123,126$.

160543 U.S. 111 (2004). See supra text accompanying notes 132-133.

161 Trademark Law Revision Act of 1988, Pub. L. No. 100-667, 102 Stat. 3935 (1988) (codified at 15 U.S.C. \$1051 (2000)).

162 Federal Trademark Dilution Act of 1995, P’ub. L. No. 104-98, 109 Stat. 985 (1996) (originally codified at 15 U.S.C. $\$ 1051,1125$, 1127 (1996), amended in 2006).

163 Trademark Dilution Revision Act of 2006, Pub. L. 109-312, 120 Stat. 1730 (2006) (codified at 15 U.S.C. \$1125(c) (2006) and replacing the Federal Trademark Dilution Act, Pub. L. 104-98).

164 Moseley v. V Secret Catalogue, Inc, 537 U.S. 418 (2003).

165 Anticybersquatting Consumer Protection Act, P'ub. L. No. 106-113, 113 Stat. 1501 (1999) (codified in scattered sections of 15 U.S.C.). 
jurisdiction for a trademark cause of action to be found in rem. ${ }^{165}$ Additionally, the new act also contains provisions for statutory damages. ${ }^{167}$ Never before in the history of the United States had in rem jurisdiction for any trademark related cause of action been recognized. Never before in the history of the United States has statutory damages been recognized in a trademark case.

Therefore, it is safe to say that the Supreme Court and the United States Congress do not agree on the appropriate scope of trademark protection or, more generally, on precisely what the parameters of trademark jurisprudence are.

\section{Normative Result: The US Protects the Personality of a Trademarkt}

Therefore, the result of this is that the lower courts have been forced by Congress to recognize a new breed of trademark jurisprudence. This new breed of trademark jurisprudence is not set upon the trademark right being a right of exclusion where the claimant is allowed to enforce a mark to the extent that they use it and as long as they use it. This used to be called the Law and Prophets of trademark jurisprudence. ${ }^{\text {tis }}$
Instead, today, the personality of the trademark is protected. The source denoting function of trademark protection has been usurped by Congress. That right is now better described as the right of attribution. Trademark owners are no longer the owner of just a right to exclude others to the extent they use the mark and for as Iong as they use the mark. Now, the source denoting function of a mark has become a moral right of attribution: a personal right of the holder of the trademark.

When a famous mark is used on unrelated goods today, Congress and the lower courts claim that the mark as been diluted. However, there is no conceptual justification under the original trademark jurisprudence in the United States to support the notion of trademark dilution. ${ }^{169}$ It is fully supported if one accepts the moral right of integrity of a mark. Under this notion, any subsequent use by anyone on unrelated goods operates just like the moral right of integrity. The trademark owner has the absolute right to protect the integrity (Congress this the protection of distinctiveness $)^{\text {to }}$ of its mark.

Therefore, the nature of trademark jurisprudence in America has changed. In the times of Learned Hand, it was a mere tort where harm in the form of confusion had to be alleged and proved before

166 See 15 U.S.C. $\$ 1125(d)(2)(2006)$.

167 See 15 U.S.C. $\$ 1177($ d) (2006)

168 Yale Elec. Corp. v. Robertson, 26 F.2d 972,973 (2d Cir. 1928) ("The law of unfair trade comes down very nearly to this-as judges liave repeated again and again-that one merchant shall not divert customers from another by representing what he sells as emanating from the second. This has been, and perhaps even more now is, the whole Law and the Proplets on the subject though it assumes many guises. $\left.{ }^{\prime \prime}\right)$.

169 Moseley v. V Secret Catalogue, Inc., 537 U.S. 418,429 (2003) ("Unlike traditional intringement law, the prolibitions against trademark dilution are not the product of common-kaw development, and are nol motivated an interest in protecting the consumers." ); see also, Delflache suma note 126, at 126 (citing the 1927 Harvard Law Review arlicle written by Frank I. Schecter on which the foundation of our modern trademark theory lies).

170 The Trademark Dilution Revision Act of 2006 explicitly provides protection for marks which are either inlierently distinctive or those which have acquired distinctiveness, from dilution or diminishment of that distinclive quality. 15 U.S.C. \$1125(c) (Lanham Act \$ 42). Likewise, the moral right of integrify serves the sole purpose of protecting that same distinctive quality by limiling the public's ability to alter a given work. BLACK'S LAw DKTHONARY 675 (81h ed. 2004). 
recovery could be had. Today, the personality of the mark is protected. The trademark holder's personality (in the form of reputation) has merged with the expression of its trademark.

The primary problem with this is that the Constitution upon which the federal trademark right is based ${ }^{n 1}$ has not changed while the trademark right has gone through this metamorphosis. The Com merce Clause, has not changed. Therefore, actual commerce is still constitutionally required before federal trademark protection is authorized. Although the Lanham Act was selectively amended to make this metamorphosis possible, neither the leg. islative history nor the fundamental aspects of the Lanham Act have changed.

If the a trademark metamorphosis was desired, our society ought to go through some thought and introspection regarding the appropriate scope of trademark protection. The Lanham Act should not be changed to simply be responsive to some lobbyist's demands ${ }^{172}$ or some specific company or industry's concerns. ${ }^{133}$ The appropriate scope of trademark protection affects us all.17/ As such, we all ought to be involved in the discussion, not just some Congresspeople who become con vinced that some element of the Lanham Act needs tweaking. Orer the last 20 years, this tweaking has transformed trademark jurisprudence in the United States from a tort in the form of a right of exclusion to an inalienable moral right where the personality of the trademark has an existence and that existence is ascribed to the holder of the mark and is protected as such.

The net result of the various amendments and the various lower court opinions is that the trademark right has been transformed. The lower courts have plenty of direction from the Supreme Court that the expansion of trademark jurisprudence should be slowed down. However, the lower courts seem to be embracing the notion of expansion of trademark rights focusing, instead, on the will of Congress even beyond what is literally required by the Lanham Act. ${ }^{13}$

171 U.S. Const. art. I, $\$ 8, \mathrm{cl} .3$

172 The reasons suggested by manulacturers for extending protection of their famous marks were "(1) they had invested time and effort in cultivation these famous mark and thus deserved legal protection; and (2) other countries already had such prohibition and it was important that the United States not lag behind any nation in the strength of its intellectual-property proetctions." William W. Fisher III, Geistiges Eigenhwn-ein ausufender Redisbereich: Die Geschidhte des Ideenschutzes in den Vereinigten Staten in Eigentum im inter-

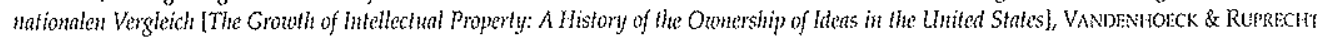
265,283 (1999) (E.R.G); see H.R. REP. No. 104-374, at 3 (1995), reprinted in 1996 U.S.C.C.A.N 1029, 1030 (noting the 'substantial investment' made by various lamous mark holders as a reason for the legislation).

173 Creative industries such as film production, new product development, publishers, and the like are constanlly pushing for increased intellectual property protection as their profitability heavily depends upon it. William W. Fisher Ill, Geistiges Eigentum-ein ausufender Rechisbereich: Dic Geschichte des ldeenschutzes in den Vereinigten Stanten in Eigenhm in internationalen Vergleich (The Growh of

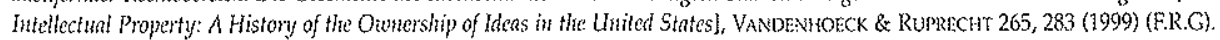

174. How and to what end the scope of trademark protection affects all individuals of society is debatable yet the fact that it does is undeniable. Compare Deborah R. Gerhard, Consmer lmestment in Trademark, 88 N.C. L. Rrv, 427 (2010) (arguing that the public interest deserves more consideration when deciding trademark matters for the investment made by consumer through brand loyalty), and Kristan Friday, Does Dihution Make Trademarks into Unconstilutiond Patents?, 12 I. CoNtemi?. Lecat Issuls 180, 181 (stating that the FTDA authorizes a legal monopoly on a mark and impairs olhers ability to make use of that mark), with Mattias Strasser, The Rational Basis of Trademark Protection Revisited: Putting the Dilution Doctrine into Context, 10 ForoHaM INTEL. Prop. MEDA \& ENT. L.). 375, 425 (2000) (arguing that for trademarks to continue to fulfill their economic purpose, protection against dilution is essential despite the potential anti-competitive result).

175 Lower courts are expanding tademark rights by redefining trademark use, Stephanie Yu Lim, Conment, Can Googhe be Liable for Tradematk Infrigement? A Look al the "Trademark Use" Requirement as Applied to Google Awords, 14 UCLA ENT. L. Rev. 265, 278, (2007) (citing Google v. American Blind, No. C 03.05340 JF, 2005 U.S. Dist. LEXIS 6228 (N.D. Cal. Mar. 30, 2005), by extending the concept of actionable consumer confusion, and by widening the class of people who can be held accountable for consumer confusion. Stacey L Dogan \& Mark A. Lemley, Trademark in Trmsition Institute for Intellecinal Properly \& Information Law Symposim, 41 Hous. L. Rkv. 777,777 (2004). 


\section{Conclusion}

Trademark rights in the United States continue to expand. The incontestability provisions of the original Lanham Act were an expansion not known to the common law. The ITU provisions, where an applicant can register his/her intent to use a trademark without actually doing so, changes the nature of the trademark system in the United States which, for over 200 years, has required actual commerce prior to Congressional action to provide federal trademark protection. Dilution law further extends the trademark right and allows trademark holders to prevent use of their mark by noncompetitors on noncompeting goods. Section 43(a) has gradually expanded over the entire life of the Lanham Act to now not only protect color alone as a trademark but even such things as the opening motion of a Lamborghini car door.
The result of this expansion is that American trademark jurisprudence has come to resemble the moral rights of attribution and integrity of the Civil Law world. This means that the trademark right is far stronger than it was in previous decades. This also means that it operates as a more effective sword in the world of corporate competition.

This entire expansion trajectory has happened slowly but inextricably behind closed doors. Congress has made incremental changes over the years that add up to the creation of a new trademark jurisprudence, one that resembles the moral rights of attribution and integrity rather than one honest to the historical roots of trademark jurisprudence. If the United States is to so fundamentally change our trademark jurisprudence, a broader debate is required. 